\title{
Encephalopathy and bilateral thalamic lesions in a child with MIS-C associated with COVID-19
}

Dori Abel, MD, Min Ye Shen, MD, Zaynah Abid, MD, MPH, Claire Hennigan, MD, Alexis Boneparth, MD, Emily Happy Miller, MD, PhD, Anne-Catrin Uhlemann, MD, PhD, Danielle K. McBrian, MD, Kiran Thakur, MD, Wendy Silver, MD, MA, and Jennifer M. Bain, MD, PhD

Neurology ${ }^{\circledR}$ 2020;95:745-748. doi:10.1212/WNL.0000000000010652

The severe acute respiratory syndrome coronavirus 2 (SARS-CoV-2) pandemic, characterized predominantly by respiratory symptoms, has affected a small subset of children. Neurologic manifestations have been described in adults, including encephalitis/meningitis, encephalopathy, strokes, seizures, and anosmia, ${ }^{1,2}$ but there are few reports of neurologic manifestations in children with SARS-CoV-2. ${ }^{3}$

Multisystem inflammatory syndrome in children (MIS-C) has been reported in children following infection with SARS-CoV-2. MIS-C is characterized by a Kawasaki-like illness with persistent fever, elevated inflammatory markers, and multisystem organ involvement. ${ }^{4} \mathrm{Al}-$ though altered mental status has been described in the presence of MIS-C, ${ }^{5}$ there are rare reports of severe encephalopathy or focal brain lesions in children with MIS-C.

We report a case of a 2-year-old with MIS-C presenting with altered mental status, who was found to have abnormal EEG and MRI findings.

\section{Case}

A previously healthy 33-month-old boy presented to the emergency department with 2 days of fever, emesis, and rash. Examination revealed a tachycardic, interactive toddler with erythematous macules on his thighs. Nasopharyngeal SARS-CoV-2 reverse transcription PCR testing was initially negative; the repeat test was indeterminate. SARS-CoV-2 antibody testing was positive. Laboratory findings were remarkable for normal white blood cell count with bandemia and elevated inflammatory markers. Chest radiograph was unremarkable. Cardiac markers were normal; echocardiogram showed trace pericardial effusion. Electrocardiogram demonstrated sinus tachycardia without improvement with fluid resuscitation. He was admitted to the hospital and treated with empiric antibiotic therapy for 48 hours, IV methylprednisolone, IV immunoglobulin (IVIG), anakinra, prophylactic anticoagulation, and supportive therapy for a presumed diagnosis of MIS-C. The figure depicts the patient's clinical course.

The patient developed worsening respiratory status over the subsequent $24-48$ hours, requiring noninvasive respiratory support and diuresis. He was irritable, but alert and active. Chest radiograph displayed bilateral pleural effusions. Echocardiogram revealed decreased left ventricular systolic function. Laboratory findings demonstrated uptrending inflammatory and cardiac markers and thrombocytopenia. On hospital day 6, he became increasingly somnolent in the absence of sedative medication.

\author{
Correspondence \\ Dr. Abel \\ dna9003@nyp.org
}

MORE ONLINE

COVID-19 Resources

For the latest articles, invited commentaries, and blogs from physicians around the world NPub.org/COVID19

From the Columbia University Irving Medical Center (D.A., C.H., Z.A., A.B.), Department of Pediatrics, NewYork-Presbyterian Hospital; Columbia University Irving Medical Center (M.Y.S.), Department of Neurology, NewYork-Presbyterian Hospital; Columbia University Irving Medical Center (E.H.M., A.-C.U.), Department of Medicine, Division of Infectious Diseases, NewYork-Presbyterian Hospital; Columbia University Irving Medical Center (D.K.M., W.S., J.M.B.), Department of Neurology, Division of Child Neurology, NewYorkPresbyterian Hospital; and Columbia University Irving Medical Center (K.T.), Department of Neurology, NewYork-Presbyterian Hospital.

Go to Neurology.org/N for full disclosures. Funding information and disclosures deemed relevant by the authors, if any, are provided at the end of the article. 


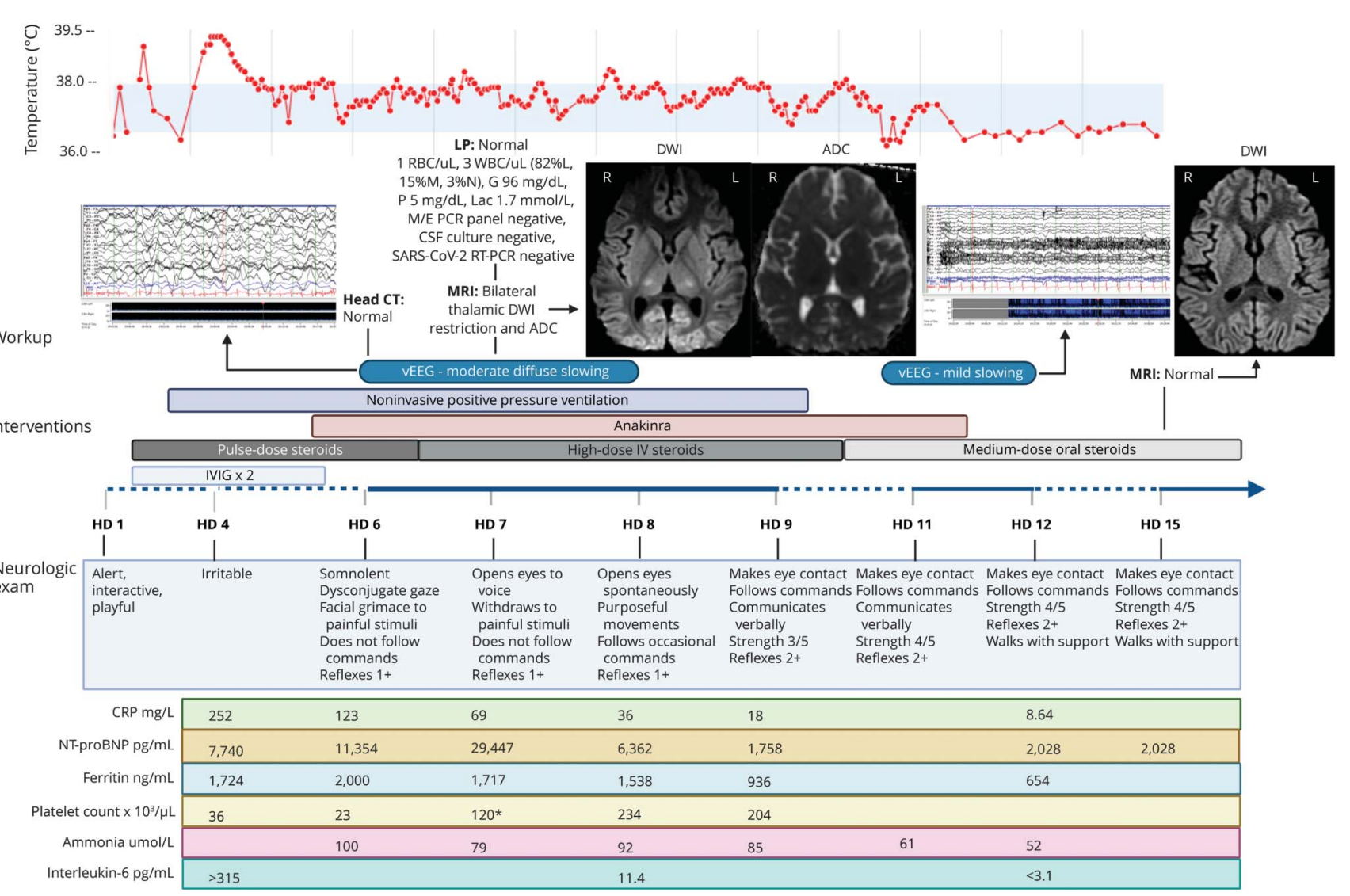

ADC = apparent diffusion coefficient; CRP = C-reactive protein; DWI = diffusion-weighted imaging; G = glucose; HD = hospital day; IVIG = IV immunoglobulin; L = lymphocytes, $M=$ monocytes; Lac = lactic acid; LP = lumbar puncture; M/E = meningitis/encephalitis; N = neutrophils; NT-proBNP = N -terminal-pro-B-type natriuretic peptide; $\mathrm{P}=$ protein; $\mathrm{pg} / \mathrm{mL}=$ picogram/milliliter; $\mathrm{RBC}=$ red blood cell; SARS-CoV-2 RT-PCR = severe acute respiratory syndrome coronavirus 2 reverse transcription $\mathrm{PCR}$; $\mathrm{WBC}=$ white blood cell. *Postplatelet transfusion.

On neurology consultation, the patient was somnolent, with slight facial grimace to noxious stimuli, diffuse hypotonia, and significant weakness. No visual changes were noted. Metabolic workup was only notable for hyperammonemia, and hepatic function was normal. Noncontrast head CT was normal. Lumbar puncture was unremarkable, including negative SARS-CoV-2 PCR in CSF. EEG showed moderate background slowing.

The following day, he remained somnolent on bilevel positive airway pressure, although with slight improvement in mental status, noted by eye opening to voice and withdrawal from noxious stimuli. His EEG was unchanged. Brain MRI revealed restricted diffusion in the bilateral lateral thalamic nuclei without $\mathrm{T} 2 /$ fluid-attenuated inversion recovery changes.

The patient's neurologic status continued to improve, and his fevers were treated with antipyretics; no additional neuroprotective strategies were used. On hospital day 9, he was consistently following commands, communicating verbally, and regaining his motor function, although he remained weak. By day 12, he was walking with support. Repeat EEG showed only mild diffuse slowing, and repeat brain MRI on day 15 showed resolution of the thalamic lesions. Brain magnetic resonance angiography and magnetic resonance spectroscopy were also normal. He was discharged home on day 15 on oral steroids, with mild residual weakness requiring physical therapy. Follow-up brain imaging has not yet been obtained.

\section{Discussion}

We report a case of a previously healthy child who met the criteria for MIS-C and developed reversible encephalopathy with moderate EEG slowing and bilateral thalamic lesions, which improved with continued treatment of his inflammatory syndrome.

There was no identified etiology for the diffuse slowing on EEG and brain MRI findings, as the patient never received sedatives or antiseizure medications, had no diffuse hypoxic events, and metabolic derangement was solely notable for moderately elevated ammonia, without other laboratory data suggestive of liver failure or hepatic encephalopathy. Despite ongoing elevated ammonia, he clinically improved. EEG findings in adults with SARS-CoV-2 have included slowing 
with a disorganized background and epileptiform discharges; however, most of these adults were receiving sedation and/or antiseizure medication. ${ }^{6}$

A multicenter study characterized neuroimaging findings in adults with SARS-CoV-2 and neurologic symptoms, finding ischemic infarcts in $31 \%$, intracranial hemorrhage in 6\%, and nonspecific T2/fluid-attenuated inversion recovery hyperintensity with restricted diffusion in a few patients. ${ }^{7}$ None had distinct thalamic lesions. Bilateral thalamic lesions have been seen in children with encephalitis associated with respiratory and West Nile viruses ${ }^{8}$; however, thalamic lesions associated with SARS-CoV-2 infection are rare. There are case reports of COVID-19associated acute necrotizing encephalopathy with characteristic bilateral thalamic hemorrhagic lesions, ${ }^{9}$ but there was no evidence on susceptibility-weighted imaging to suggest a hemorrhagic component in this patient.

Although MIS-C affects multiple organ systems, we are unaware of other patients with associated encephalopathy, EEG slowing, and thalamic lesions. Some have posited that encephalopathy associated with SARS-CoV-2 infection may be attributable to direct CNS infection and have found increased levels of cytokines and antibodies against SARS-CoV-2 in affected patients' CSF. ${ }^{10}$ We suggest that this patient's encephalopathy may reflect CNS effects of his marked systemic inflammatory response, rather than direct entry of the virus into the CNS, as the encephalopathy paralleled his increasing laboratory inflammation, and CSF SARS-CoV-2 PCR was negative. Encephalopathy has also been described in postviral autoimmune encephalitis after herpes virus infections. ${ }^{11}$ The etiology of MIS-C is unclear, but it has been postulated that it arises from postinfectious, acquired immune activation. ${ }^{12}$ MIS-C and Kawasaki disease have overlapping features, and current evidence suggests that patients with MIS-C have good outcomes after treatment with immunomodulatory therapies such as IVIG and corticosteroids. ${ }^{13}$ The patient had elevated interleukin-6 at the onset of his encephalopathy, which downtrended as he clinically improved. If the patient's CNS manifestations reflect his systemic inflammatory response in the setting of MIS-C, this supports immune modulation as treatment, including corticosteroids, IVIG, and anakinra, as opposed to antiviral therapy.

Given the prevalence of SARS-CoV-2 and the growing numbers of children with MIS-C, it is imperative that we investigate the underlying etiology of associated neurologic manifestations and the appropriate therapies for these patients.

\section{Acknowledgment}

The authors thank the patient and his family, the physicians, nurses, medical assistants, and support staff involved in the care of this patient and the microbiology and core laboratory staff.

\section{Study funding}

No targeted funding reported.

\section{Disclosure}

The authors report no disclosures relevant to the manuscript. Go to Neurology.org/N for full disclosures.

\section{Publication history}

Received by Neurology June 16, 2020. Accepted in final form August 3, 2020.

\begin{tabular}{lll} 
Appendix & Authors & \\
\hline Name & Location & Contributions \\
\hline $\begin{array}{lll}\text { Dori Abel, } \\
\text { MD }\end{array}$ & $\begin{array}{l}\text { Columbia University Irving } \\
\text { Medical Center, Department } \\
\text { of Pediatrics; NewYork- } \\
\text { Presbyterian Hospital; New } \\
\text { York }\end{array}$ & $\begin{array}{l}\text { Designed and } \\
\text { conceptualized the } \\
\text { report; acquired and } \\
\text { analyzed data; and } \\
\text { drafted and revised the } \\
\text { manuscript }\end{array}$ \\
\hline
\end{tabular}

\begin{tabular}{lll}
\hline Min Ye Shen, & $\begin{array}{l}\text { Columbia University Irving } \\
\text { Medical Center, Department } \\
\text { of Neurology; NewYork- } \\
\text { Presbyterian Hospital; New } \\
\text { York }\end{array}$ & $\begin{array}{l}\text { Acquired and analyzed } \\
\text { data and drafted and } \\
\text { revised the manuscript }\end{array}$ \\
\end{tabular}

\begin{tabular}{lll}
\hline Zaynah Abid, & Columbia University Irving & Acquired and analyzed \\
MD, MPH & Medical Center, Department & data and drafted the \\
of Pediatrics; NewYork- & manuscript \\
& $\begin{array}{l}\text { Presbyterian Hospital; New } \\
\text { York }\end{array}$ & \\
&
\end{tabular}

\begin{tabular}{|c|c|c|}
\hline $\begin{array}{l}\text { Claire } \\
\text { Hennigan, } \\
\text { MD }\end{array}$ & $\begin{array}{l}\text { Columbia University Irving } \\
\text { Medical Center, Department } \\
\text { of Pediatrics; NewYork- } \\
\text { Presbyterian Hospital; New } \\
\text { York }\end{array}$ & $\begin{array}{l}\text { Acquired and analyzed } \\
\text { data and drafted the } \\
\text { manuscript }\end{array}$ \\
\hline
\end{tabular}

\begin{tabular}{lll}
\hline Alexis & Columbia University Irving & Revised the manuscript \\
Boneparth, & Medical Center, Department & \\
MD & of Pediatrics; NewYork- & \\
& $\begin{array}{l}\text { Presbyterian Hospital; New } \\
\text { York }\end{array}$ \\
\hline
\end{tabular}

\begin{tabular}{lll}
\hline $\begin{array}{l}\text { Emily Happy } \\
\text { Miller, MD, } \\
\text { PhD }\end{array}$ & $\begin{array}{l}\text { Columbia University Irving } \\
\text { Medical Center, Department } \\
\text { of Medicine, Division of } \\
\text { Infectious Diseases; } \\
\text { NewYork-Presbyterian } \\
\text { Hospital; New York, NY }\end{array}$ & Acquired data \\
\hline $\begin{array}{l}\text { Anne-Catrin } \\
\text { Uhlemann, } \\
\text { MD, PhD }\end{array}$ & $\begin{array}{l}\text { Columbia University Irving } \\
\text { Medical Center, Department } \\
\text { of Medicine, Division of } \\
\text { Infectious Diseases; }\end{array}$ & Acquired data \\
& $\begin{array}{l}\text { NewYork-Presbyterian } \\
\text { Hospital; New York, NY }\end{array}$ & \\
\hline $\begin{array}{ll}\text { Danielle K. } \\
\text { McBrian, MD }\end{array}$ & $\begin{array}{l}\text { Columbia University Irving } \\
\text { Medical Center, Department } \\
\text { of Neurology, Division of } \\
\text { Child Neurology; NewYork- }\end{array}$ & Acquired data \\
& $\begin{array}{l}\text { Presbyterian Hospital; New } \\
\text { York }\end{array}$ \\
\hline Kiran & $\begin{array}{l}\text { Columbia University Irving } \\
\text { Thakur, MD }\end{array}$ & Medical Center, Department \\
& of Neurology; NewYork- & \\
& $\begin{array}{l}\text { Presbyterian Hospital; New } \\
\text { York }\end{array}$ \\
\hline
\end{tabular}

Continued 
Appendix (continued)

\begin{tabular}{|c|c|c|}
\hline Name & Location & Contributions \\
\hline $\begin{array}{l}\text { Wendy } \\
\text { Silver, MD, } \\
\text { MA }\end{array}$ & $\begin{array}{l}\text { Columbia University Irving } \\
\text { Medical Center, Department } \\
\text { of Neurology, Division of } \\
\text { Child Neurology; NewYork- } \\
\text { Presbyterian Hospital; New } \\
\text { York }\end{array}$ & $\begin{array}{l}\text { Interpreted data and } \\
\text { revised the manuscript }\end{array}$ \\
\hline $\begin{array}{l}\text { Jennifer M. } \\
\text { Bain, MD, } \\
\text { PhD }\end{array}$ & $\begin{array}{l}\text { Columbia University Irving } \\
\text { Medical Center, Department of } \\
\text { Neurology, Division of Child } \\
\text { Neurology; NewYork- } \\
\text { Presbyterian Hospital; New York }\end{array}$ & $\begin{array}{l}\text { Designed and } \\
\text { conceptualized the } \\
\text { report; interpreted data; } \\
\text { and revised the } \\
\text { manuscript }\end{array}$ \\
\hline
\end{tabular}

\section{References}

1. Mao L, Jin H, Wang M, et al. Neurologic manifestations of hospitalized patients with coronavirus disease 2019 in Wuhan, China. JAMA Neurol 2020;77:1-9.

2. Koralnik IJ, Tyler KL. COVID-19: a global threat to the nervous system. Ann Neurol 2020;88:1-11.

3. Dugue R, Cay-Martínez KC, Thakur KT, et al. Neurologic manifestations in an infant with COVID-19. Neurology 2020;94:1100-1102.
4. Whittaker E, Bamford A, Kenny J, et al. Clinical characteristics of 58 children with a pediatric inflammatory multisystem syndrome temporally associated with SARS CoV-2. JAMA 2020;e2010369.

5. Chiotos K, Bassiri H, Behrens EM, et al. Multisystem inflammatory syndrome in children during the COVID-19 pandemic: a case series. J Pediatr Infect Dis Soc 2020; 9:393-398.

6. Galanopoulou AS, Ferastraoaru V, Correa DJ, et al. EEG findings in acutely ill patients investigated for SARS-CoV-2/COVID-19: a small case series preliminary report. Epilepsia Open 2020;5:314-324.

7. Mahammedi A, Saba L, Vagal A, et al. Imaging in neurological disease of hospitalized COVID-19 patients: an Italian multicenter retrospective observational study. Radiology 2020:201933.

8. Beattie GC, Glaser CA, Sheriff H, et al. Encephalitis with thalamic and basal ganglia abnormalities: etiologies, neuroimaging, and potential role of respiratory viruses. Clin Infect Dis 2013;56:825-832.

9. Poyiadji N, Shahin G, Noujaim D, Stone M, Patel S, Griffith B. COVID-19-associated acute hemorrhagic necrotizing encephalopathy: CT and MRI features. Radiology 2020:296:E119-E120.

10. Benameur K, Agarwal A, Auld SC, et al. Encephalopathy and encephalitis associated with cerebrospinal fluid cytokine alterations and coronavirus disease, Atlanta, Georgia, USA, 2020. Emerging Infect Dis 2020;26;26.

11. Prüss $\mathrm{H}$. Postviral autoimmune encephalitis: manifestations in children and adults. Curr Opin Neurol 2017;30:327-333.

12. Verdoni L, Mazza A, Gervasoni A, et al. An outbreak of severe Kawasaki-like disease at the Italian epicentre of the SARS-CoV-2 epidemic: an observational cohort study. Lancet 2020;395:1771-1778.

13. Feldstein LR, Rose EB, Horwitz SM, et al. Multisystem inflammatory syndrome in U.S. children and adolescents. N Engl J Med 2020;383:334-346.

\section{NEW EPISODE}
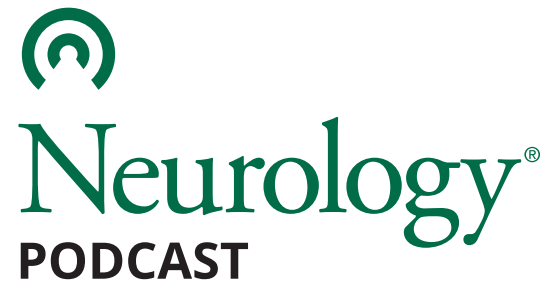

October 20, 2020

\section{New-onset super-refractory status epilepticus: A case series of 26 patients (see p. 724)}

In the first segment, Dr. Jeffrey Ratliff talks with Dr. Elizabeth Matthews about her paper on super-refractory status epilepticus. Then, Dr. Jason Crowell speaks with Matthew Futterman about his New York Times article on neurologic sequela in sledding athletes. Read the NYT article here: https://nyti.ms/3mNBlhE.

Disclosures can be found at Neurology.org.

CME Opportunity: Listen to this week's Neurology Podcast and earn 0.5 AMA PRA Category 1 CME Credits ${ }^{\mathrm{TM}}$ by completing the online Podcast quiz. 


\section{Neurology}

\section{Encephalopathy and bilateral thalamic lesions in a child with MIS-C associated with COVID-19}

Dori Abel, Min Ye Shen, Zaynah Abid, et al.

Neurology 2020;95;745-748 Published Online before print August 26, 2020

DOI 10.1212/WNL.0000000000010652

This information is current as of August 26, 2020

\section{Updated Information \& Services}

References

Citations

Subspecialty Collections

Permissions \& Licensing

Reprints including high resolution figures, can be found at: http://n.neurology.org/content/95/16/745.full

This article cites 11 articles, 1 of which you can access for free at: http://n.neurology.org/content/95/16/745.full\#ref-list-1

This article has been cited by 2 HighWire-hosted articles: http://n.neurology.org/content/95/16/745.full\#\#otherarticles

This article, along with others on similar topics, appears in the following collection(s):

\section{All Immunology}

http://n.neurology.org/cgi/collection/all_immunology

\section{All Pediatric}

http://n.neurology.org/cgi/collection/all_pediatric

Information about reproducing this article in parts (figures,tables) or in its entirety can be found online at:

http://www.neurology.org/about/about_the_journal\#permissions

Information about ordering reprints can be found online:

http://n.neurology.org/subscribers/advertise

Neurology ${ }^{\circledR}$ is the official journal of the American Academy of Neurology. Published continuously since 1951, it is now a weekly with 48 issues per year. Copyright Copyright (C) 2020 The Author(s). Published by Wolters Kluwer Health, Inc. on behalf of the American Academy of Neurology.. All rights reserved. Print ISSN: 0028-3878. Online ISSN: 1526-632X.

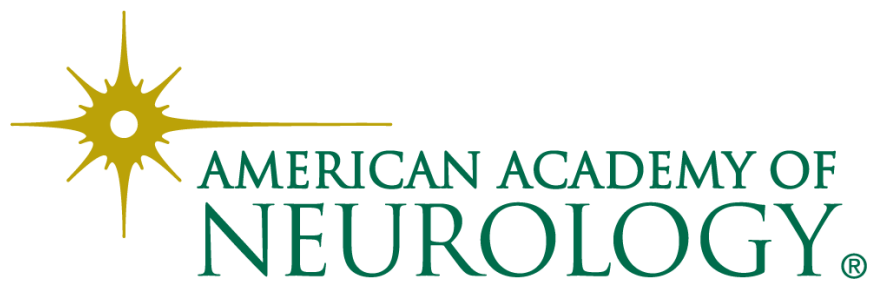

